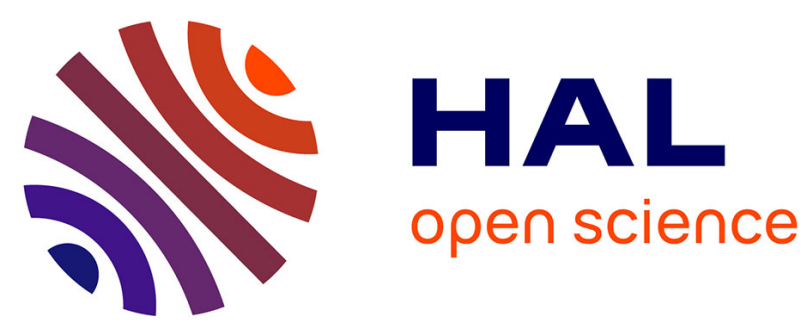

\title{
Impacts of land use on hydrodynamic properties and pore architecture of volcanic soils from the Mexican Highlands
}

C. Duwig, B. Prado, A.-J. Tinet, P. Delmas, N. Dal Ferro, J. Vandervaere, H. Denis, P. Charrier, A. Gastelum Strozzi, F. Morari

\section{To cite this version:}

C. Duwig, B. Prado, A.-J. Tinet, P. Delmas, N. Dal Ferro, et al.. Impacts of land use on hydrodynamic properties and pore architecture of volcanic soils from the Mexican Highlands. Soil Research, 2019, 57 (6), pp.629-641. 10.1071/SR18271 . hal-02458483

\section{HAL Id: hal-02458483 \\ https://hal.univ-lorraine.fr/hal-02458483}

Submitted on 19 Oct 2020

HAL is a multi-disciplinary open access archive for the deposit and dissemination of scientific research documents, whether they are published or not. The documents may come from teaching and research institutions in France or abroad, or from public or private research centers.
L'archive ouverte pluridisciplinaire HAL, est destinée au dépôt et à la diffusion de documents scientifiques de niveau recherche, publiés ou non, émanant des établissements d'enseignement et de recherche français ou étrangers, des laboratoires publics ou privés. 


\title{
Impacts of land use on hydrodynamic properties and pore architecture of volcanic soils from the Mexican Highlands
}

\author{
C. Duwig A, B. Prado B,H, A.-J. Tinet C, P. Delmas D, N. Dal Ferro E, \\ J. P. Vandervaere ${ }^{\mathrm{A}}, H$. Denis ${ }^{\mathrm{A}}$, P. Charrier $^{\mathrm{F}}, A$. Gastelum Strozzi $\mathrm{G}$, and F. Morari ${ }^{\mathrm{E}}$ \\ AUniversité Grenoble Alpes, CNRS, IRD, Grenoble INP, IGE, F-38000 Grenoble, France. \\ ${ }^{B}$ Instituto de Geología, Universidad Nacional Autónoma de México, Cuidad de México, Mexico. \\ CUniversité de Lorraine, CNRS, GeoRessources, F-54000 Nancy, France. \\ DDepartment of Computer Science, The University of Auckland, Auckland, New Zealand. \\ EDepartment of Agronomy, Food, Natural Resources, Animals and Environment, Agripolis, \\ 10 University of Padova, Viale Dell’Università 16, 35020 Legnaro, Italy. \\ FUniversité Grenoble Alpes, CNRS, Grenoble INP, 3SR, F-38000 Grenoble, France. \\ ${ }^{\mathrm{G}}$ Centro de Ciencias Aplicadas y Desarrollo Tecnológico, Universidad Nacional Autónoma de Mexico, \\ Mexico, D.F., México. \\ ${ }^{\mathrm{H}}$ Corresponding author. Email: bprado@geologia.unam.mx
}

\begin{abstract}
Volcanic soils are important resources because of their unique mineralogical and physical characteristics, and allophanic Andosols represent some of the world's most fertile soils. However, their unique properties can be lost when cultivated. Most soils in the Central Valley, Mexico, are derived from volcanic materials. This valley encompasses one of the largest water supply systems in the world by volume, but is affected by soil degradation and deforestation. Sustainably managing volcanic soils requires understanding how land use affects their hydrodynamic properties. Gas adsorption and mercury intrusion porosimetry, water retention curves, tension infiltrometry and X-ray tomography were used to describe pore structure characteristics. Two volcanic soils (one Andosol and one derived from indurated tuff - Tepetates), three land uses (maize monoculture, maize-wheat rotation and fallow) and two horizons (Ap and A2 for maize monoculture and maize-wheat rotation) were studied. Tillage affected topsoil by increasing the sand fraction by $38 \%$ and decreasing total porosity and macroporosity by $23 \%$ and $40 \%$ respectively. Macropore size was reduced and the number of isolated macropores was higher in the tilled layer under maize, compared with untilled subsoil. The plot under maize-wheat rotation had lower allophane content, and saturated hydraulic conductivity was reduced by nearly an order of magnitude and water retention by half, compared with maize and fallow plots. Compared with Andosols, Tepetates showed differences in mineralogical composition with lower contents of amorphous compounds and in its porous network characteristics with twice the total and percolating macroporosity compared with the maize plot. Its high content of organic carbon (3.5\%) seemed beneficial for its hydrodynamic properties. Sustainable agricultural management of these volcanic soils requires reducing mechanised tillage, avoiding periods when soil is bare, not applying maize-wheat rotation and applying maize-fallow rotation allowing natural vegetation growth.
\end{abstract}

Additional keywords: Andosol, pore size distribution, X-ray tomography.

\section{Introduction}

Volcanic soils are important land resources for agriculture because of their unique properties which place them among the most productive soils in the world (Shoji et al. 1993). They cover $\sim 1 \%$ of the global surface (Arnalds and Stahr 2004) and $1.2 \%$ of Mexico (INEGI 1999). Most soils in the Mexican Highlands, where the Trans-Mexican Volcanic Belt is located, are derived from volcanic materials (Aguilera 1963).

Volcanic soil parent materials are made of volcanic ejecta, and weathering results in short-range order minerals such as allophane, imogolite, ferrihydrite and other iron (Fe) and aluminium (Al) oxyhydroxides. In particular, allophanes are fine-sized particles with hollow spherical structures (internal diameters of 3-4 nm) that can accommodate water molecules in both intra-and inter-spherical pores (Nanzyo et al. 1993a). Parfitt and Henmi (1980) suggested that the hollow spherical aluminosilicate sheet of allophanes has $0.3-\mathrm{nm}$ diameter holes that allow water molecules to pass through. These colloidal materials provide distinctive properties, termed andic properties, which differentiate volcanic soils from all other soil types. Allophanic soils generally have high organic carbon content, because of formation of stable complexes 
between humic substances and $\mathrm{Al}, \mathrm{Fe}$ and non-crystalline compounds, which are protected against microbial degradation (Nanzyo et al. 1993a). Allophanic Andosols have a strong aggregation that imparts favourable structural properties and low bulk density and high porosity resulting from the presence of amorphous materials, with a wide range of pore sizes that retain large amounts of water. Additional peculiar properties include variable charge characteristics and phosphate absorption (Arnalds and Stahr 2004).

High water permeability under both saturated and unsaturated conditions is another distinctive property of volcanic ash soils (Warkentin and Maeda 1980). At the same void ratio, allophane soils have a higher saturated hydraulic conductivity $\left(K_{\mathrm{s}}\right)$ than montmorillonite soils. Under unsaturated conditions, Andosols have a greater hydraulic conductivity than other mineral soils such as clayey alluvial soils and red/yellow soils (Nanzyo et al. 1993b).

The peculiar behaviour of Andosols can greatly change when these soils are brought into cultivation. Desiccation and compaction are two processes affecting the structure of these soils, and drying by vegetation removal results in an irreversible decrease in porosity and moisture retention (Maeda et al. 1977). The shrinkage properties of Andosols are due to microaggregations of non-crystalline components upon drying (Dorel et al. 2000). Churchman and Payne (1983) studied sandy loam soil in Taupo (New Zealand), with allophanes dominating the clay fraction. Soil porosity was dominated by large stable pores $(>1000 \mathrm{~nm})$; while a loss in the $10-100 \mathrm{~nm}$ range occurred upon oven drying. The coalescence of microaggregates of allophanes into larger aggregates via drying has been considered responsible for the loss of these fine pores. A compaction effect was observed by Cattan et al. (2006) on an Umbric Andosol; the authors found a higher hydraulic conductivity outside than inside wheel tracks of the same plot, along with a positive effect of tillage (untilled soil $K_{\mathrm{s}}=75 \mathrm{~mm} \mathrm{~h}^{-1}$, tilled soil $K_{\mathrm{s}}=265 \mathrm{~mm} \mathrm{~h}^{-1}$ ). Similarly, Dörner et al. (2010) studied the consequences of land use change from a native forest to pasture on Andosols in southern Chile and found a decrease in $K_{\mathrm{s}}$ due to mechanical stress (e.g. animal trampling).

According to Mele et al. (2000), measurements of pore size distribution (PSD) in volcanic soils, taking into account their distinctive properties, are scarce. Soil pores range in size over several orders of magnitude, especially in Andosols, and their distribution measurements must be performed by coupling different methods, each providing results within a specific pore range. Poulenard et al. (2002) combined vacuum-drying techniques with mercury intrusion porosimetry determination to evaluate the drainage porosity in Andosols from Ecuador. In another study, Basile et al. (2007) performed detailed measurements of hydraulic properties on volcanic soils and related them to their distinct hydrodynamic behaviour and characteristics. Duwig et al. (2008) coupled dye infiltration with image analysis to illustrate finger-type flows in the same Mexican allophanic Andosols. More recently, X-ray tomography was used to quantify pore morphological parameters of Andosols and was coupled with hydrological analyses (Vingiani et al. 2015; Müller et al. 2018).

The Mexican Highlands are under arid and semiarid climatic conditions and receive less than $20 \%$ of the nation's precipitation, while containing $75 \%$ of the 97 million inhabitants, $70 \%$ of the industry and $40 \%$ of the agriculture of the country (Semarnat 2000). The natural vegetation of the high Mexican Altiplano is grassland and pine forest and when the soils are brought into cultivation, they rapidly lose their organic carbon stock in the uppermost horizon (Dubroeucq et al. 2002), which might lead to a decrease in their water retention capacity and changes in the hydrological regime (Dorel et al. 2000). In the Mexican Highlands, there is currently a predominance of continuous maize monoculture wherever moisture permits, and mechanical tillage has begun to be widespread, at least for land preparation for seeding. Although fertiliser input appears to be modest, cereal grain yield is low $\left(<3 \mathrm{t} \mathrm{ha}^{-1}\right)$ and crops are nutrient-deficient (Fischer et al. 2002) because of high nutrient (especially phosphorus) retention by volcanic soils and low air temperatures, especially at high elevations. The Mexican Highland soils render important ecosystem services to one of the largest cities of the world, and thus it is necessary to understand how land use can affect soil hydrodynamic and porous properties. In this study, we investigated two soil types derived from volcanic ash and ejecta in the Mexican Highlands and compared three different land uses (maize in monoculture, maize-wheat rotation and fallow) and two horizons for the maize plots. Several in situ and laboratory techniques were employed to study the soil hydrodynamic properties, the PSD and the macropore network. The general aims were to understand how land use affects (1) hydrodynamic properties of these volcanic ash soils and (2) their porous system in order to suggest alternative cultivation practices that maintain these soils' unique physical and hydrodynamic properties.

\section{Materials and methods}

Study site

The study site was located in Valle de Bravo, a 63473- $\mathrm{km}^{2}$ watershed in the Trans-Mexican Volcanic Belt, in the western area of the State of Mexico. Valle de Bravo is part of the Balsas River hydrological region, within the Cutzamala River watershed, which provides nearly $30 \%$ of the water for Mexico City. The 'La Loma' experimental micro-catchment (53 ha) was selected to evaluate the effect of land use change on soil properties (Prado et al. 2007) and to conduct water (Prado et al. 2009), nutrient and pesticide transfer (Prado et al. 2011; Müller et al. 2012), in addition to erosion (Viramontes et al. 2008) studies and to represent the environmental conditions and land use of the Valle de Bravo basin. The catchment is located at elevations in the range of $2600-3000 \mathrm{~m}$ a.s.1. in the municipality of Amanalco de Becerra in the State of Mexico $\left(19^{\circ} 23^{\prime} 00^{\prime \prime}-19^{\circ} 05^{\prime} 30^{\prime \prime} \mathrm{N}, 100^{\circ} 11^{\prime} 40^{\prime \prime}-99^{\circ} 52^{\prime} 00^{\prime \prime} \mathrm{W}\right)$ (Fig. 1). The site is under a tropical climate of moderate altitude: maximum precipitation is during June-September, which is mainly in storm events. Mean annual precipitation and temperature are $1300 \mathrm{~mm}$ and $10.7^{\circ} \mathrm{C}$ respectively. The average Penman potential evapotranspiration is $1250 \mathrm{~mm}$.

\section{Plots studied and soil characteristics}

Andosols and indurated volcanic soils (Tepetates) are present in the La Loma catchment. Andosols are the main soil type in the 


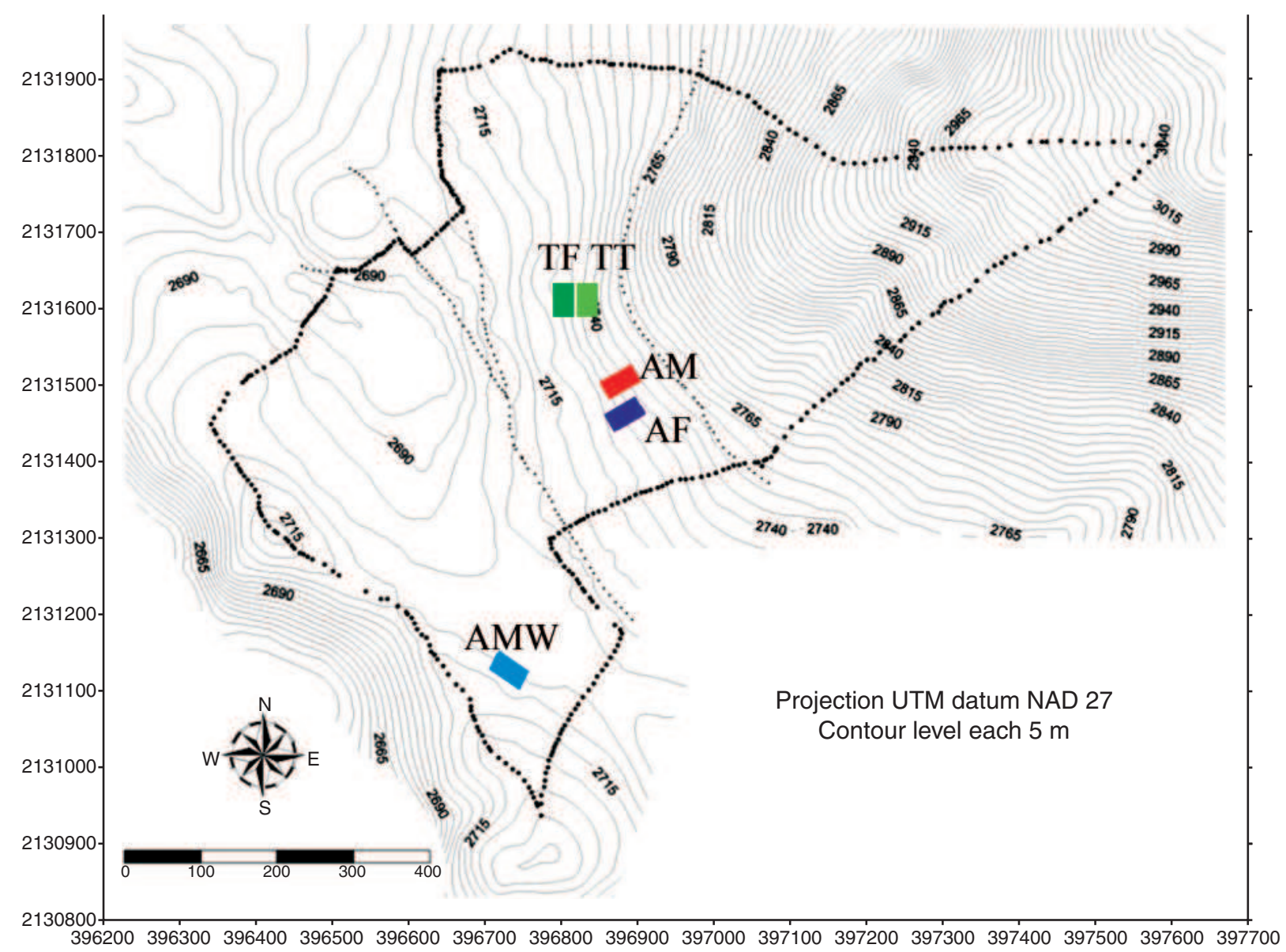

Fig. 1. Topographic map of the La Loma catchment and locations of the four studied plots. AM, Andosol under maize; AMW, Andosol under maize-wheat rotation; AF, Andosol under fallow; and TF and TT, Tepetates under fallow and freshly tilled respectively. Sources: INEGI topographic map (E14037) and IMTA data.

catchment (Prado et al. 2007), and indurated soils represent $\sim 10 \%$ of the total watershed area. 'Tepetates' is a vernacular Mexican term and refers to a hardened layer derived from tuff, pyroclastic flows or old volcanic ashes sometimes found in some soil profiles of volcanic landscapes (Etchevers et al. 2006). They usually have a texture ranging from sandy clayloam to silty clay-loam, low hydraulic conductivity and usually a higher penetration resistance in addition to low organic matter content, making them unsuitable for agricultural activities.

Five plots (Fig. 1) of $\sim 0.4$ ha were studied during 2003-2008: two plots on Andosols just after primary tillage with a mouldboard pulled by a horse (AM with maize and AMW alternately with maize and wheat), one plot on Andosol under fallow conditions (AF) and one plot each on Tepetates under fallow conditions (TF) and freshly tilled (TT). The five plots were representative of the agricultural practices (45\% under native pine and spruce trees above an elevation of $2765 \mathrm{~m}, 38 \%$ under maize and wheat, and $17 \%$ under fallow management) and soil type in the catchment. The average slopes of the studied plots were 27.9, 8.7, 20 and $13.3 \%$ for AM, AMW, AF and TT (and TF) respectively. The two maize plots (AM and AMW), were studied at two different depths: the soil surface of the Ap horizon (AM-Top and AMW-Top, 0-5 cm depth) and the A2 horizon below the ploughing depth (AM-Sub and AMW-Sub, 30-35 $\mathrm{cm}$ depth). The two depths were studied in the maize in monoculture and the maize and wheat plots to investigate the effect of ploughing on the soil physical and porous architecture properties, while only the surface layer was studied in the AF, TF and TT plots.

\section{Physical soil properties}

Physical and chemical soil properties were determined in detail in the Andosol of AM by Prado et al. (2007). This study classified the Andosol as a Typic Hapluland (FAO-ISRICISSS 1998). Infiltrometry was performed in April 2007 (just after tillage) and samples for the laboratory determination were taken at the same time, with the exception of bulk density cores which were taken several times during the study period.

In volcanic soils, it is extremely difficult to define the adequate pretreatment to determine the grain size because the fine components also act as cementing agents. Particle size was measured in triplicate with a laser granulometer (Mastersizer 2000, Malvern Instruments, Worcestershire, UK). Different treatments were tested and according to Buurman et al. (1997) and Buurman and van Doesburg (2007), and it was decided to apply the simplest treatment, i.e. soil at field capacity with sonication and without any further treatment. 
Bulk density was measured in intact soil cores of $204 \mathrm{~cm}^{3}$ (4 $\mathrm{cm}$ height and $4.03 \mathrm{~cm}$ internal diameter), sampled from each horizon and dried at $105^{\circ} \mathrm{C}$ until constant weight, measured at different times of the year during the study period (between five times for plots under fallow management and 11 times for tilled soils). No tendencies in bulk density variations with time after tillage were noticed, so the average value of all measured values was taken. The same $204-\mathrm{cm}^{3}$ cylinder was used to take intact soil cores for determination of the soil water retention curve (SWRC). The water contents at pressure heads $(h)$ of $-80,-120$ and $-150 \mathrm{~m}$ were obtained by means of a pressure membrane and the pressure heads of $-1,-3.3,-10,-20$ and $-40 \mathrm{~m}$ with a pressure plate in intact cores (Dane and Hopmans 2002). The water contents for pressure heads of $0,-0.1,-0.25,-0.4$ and $-0.6 \mathrm{~m}$ were measured in a 0-2.0 pF meter (Sand Box, Eijkelkamp, Giesbeek, Pays-Bas). Each point was measured in triplicate (except for AM-Top where only two repetitions were obtained). Hydraulic properties were measured in triplicate via a tension disc-infiltrometer (Clothier 2001) with a diameter of $0.2 \mathrm{~m}$ that was set to subsequent pressure heads of $-0.1,-0.06,-0.03$ and $-0.01 \mathrm{~m}$. A thin sand layer on top of the soil ensured good contact between the soil and the base of the infiltrometer and had no effect on the steady-state regime (Vandervaere et al. 2000).

The PSD was measured via mercury intrusion porosimetry (MIP; AutoPore IV 9500, Micromeritics) on intact aggregates of $\sim 0.5 \mathrm{~cm}^{3}$, sampled from the AM plot at the surface and at a depth of $30 \mathrm{~cm}$ (one aggregate subsampled in each of the intact cores of AM-Top and AM-Sub after being imaged by X-ray tomography). The samples were kept at field water content and were freeze-dried before the measurement in order to keep the inner structure intact. We obtained PSDs of 0.0061-402 $\mu \mathrm{m}$ in diameter.

The same aggregates were used to study the specific surface and PSD of AM-Top and AM-Sub by using a Sorptomatic 1990 (ThermoScientific, Waltham, MA, USA). The Brunauer-Emmett-Teller (BET) surface area was determined using the linear part of the $\mathrm{N}_{2}$ isotherm (between pressure $\mathrm{p} / \mathrm{p}_{\mathrm{o}} 0.05$ and 0.25 ), obtained at a temperature of $-195.15^{\circ} \mathrm{C}$ after degassing the sample at $105^{\circ} \mathrm{C}$ overnight. The PSD, including pores of radii $0.2-50 \mathrm{~nm}$, was calculated with the Barrett-Joyner-Halenda (BJH) method in the range of 1-18 nm (Barrett et al. 1951) and with the Horváth and Kawazoe (HK) method in the range of 0.4-1.6 nm (Horváth and Kawazoe 1983).

Cumulative PSD was calculated from the different methods (SWRC, MIP, BET and BJH) using capillary theory (Jurin's law). The total cumulative pore volume (normalised by the total volume) corresponded to the saturated water content as measured by the SWRC at $h=0 \mathrm{~m}$.

\section{Parametric models for hydraulic properties}

The SWRCs, representing the soil water content $(\theta)$ against the pressure head ( $h$ in $\mathrm{m}$ ), were fitted to the Brooks and Corey model (Brooks and Corey 1964):

$$
\theta=\theta_{r}+\left(\theta_{s}-\theta_{r}\right)\left[\left|\frac{h}{h_{c}}\right|\right]^{-\lambda}
$$

where $\theta_{\mathrm{s}}$ and $\theta_{\mathrm{r}}$ are saturated and residual water contents respectively $\left(\mathrm{m}^{3} \mathrm{~m}^{-3}\right), h_{c}$ is the so-called 'air-entry pressure value' (m) and $\lambda$ is a soil-dependent shape parameter. Parameters $\theta_{\mathrm{s}}, \theta_{\mathrm{r}}, h_{c}$ and $\lambda$ were fitted using the Seki (2007) SWRC-Fit software on the average values of water content.

For the determination of hydraulic conductivity vs pressure head function $K(h)$, we assumed that the flux $\left(q, \mathrm{~m} \mathrm{~s}^{-1}\right)$ under the disc was given by Wooding's equation (Wooding, 1968):

$$
q=K_{s} e^{\alpha h}\left[1+\frac{4}{\pi r \alpha}\right]
$$

where $\alpha$ is a soil-dependent parameter $\left(\mathrm{m}^{-1}\right)$ and $r(\mathrm{~m})$ is the radius of the infiltrometer disc. The $K_{\mathrm{s}}$ and $\alpha$ were determined by fitting a linear regression between $\ln (q)$ and $h$.

This fitting method considers that the hydraulic conductivity follows an exponential pattern with the pressure head (Gardner 1958):

$$
K(h)=K_{s} e^{\alpha h}
$$

The parameter $\alpha$ relates to the ratio between gravity and capillary forces. From the value of $\alpha$, the effective mean pore radius $\left(\lambda_{\mathrm{m}}\right)$ near saturation was derived following White and Sully (1987):

$$
\lambda_{\mathrm{m}}=\frac{\alpha \sigma}{\rho g}
$$

where $\sigma$ is the surface tension $\left(73 \mathrm{mN} \mathrm{m}^{-1}\right), \rho$ is the density of water $\left(\mathrm{g} \mathrm{m}^{-3}\right)$ and $g$ is the acceleration due to gravity $\left(\mathrm{m} \mathrm{s}^{-2}\right)$. The effective mean pore radius defines the mean characteristic pore size that is hydraulically functioning at the imposed water pressure head.

Following the analysis of $\mathrm{Hu}$ et al. (2009), the contribution of each pore class to the total infiltration flow under the tension disc-infiltrometer was calculated as:

$$
\varphi i(\%)=\frac{K\left(h_{i}\right)-K\left(h_{i-1}\right)}{K_{s}} \times 100, i=1, \ldots, n
$$

where $n$ is the number of infiltration tests, and $h_{\mathrm{i}}$ and $h_{\mathrm{i}-1}$ are two consecutive pressure heads that define a pore class participating to the flow, according to Watson and Luxmoore (1986).

\section{$X$-ray tomography image processing and analysis}

One intact soil core $5 \mathrm{~cm}$ in diameter and $5 \mathrm{~cm}$ in height was sampled in each of the AM-Top, AM-Sub and TF plots in April 2011. It was only possible to sample these three plots because the X-ray tomography studies were performed 4 years later than the study on soil mineralogical, physical and chemical properties (Prado et al. 2007); during this time, the land use in AMW and AF changed. We assumed that total porosity of the AM and TF soils had not changed, because we noticed that the bulk density did not change with time.

Core scanning was performed at the '3S-R' laboratory in Grenoble, using the same CT scan and settings as described in Dal Ferro et al. (2015). Projections were reconstructed using the dedicated DigiCT 1.1 software (Digisens, France). The upper and lower projections were removed, as they had insufficient soil content to obtain a stack of 10002 D slices of $1920 \times 1536$ pixels, coded as 32-bit data with a voxel resolution of $44 \mu \mathrm{m}$. 
Digital image processing and analysis were conducted using a combination of custom-made plugins and embedded functions of the public domain image-processing software ImageJ (version $1.51 \mathrm{k}$, National Institute of Health, http://rsb.info. nih.gov/ij). Slices were first pre-processed to remove inherent noise and artefacts by using 3D Gaussian and median filtering, and the resulting slices were segmented into a set of separate regions using a two-stage segmentation approach (multi-regional kriging (MRK); Azhar et al. 2019). The first stage applied the maximum entropy threshold algorithm (EM; Luo et al. 2010) and computed an estimate of the number of separate regions, assuming that the image stack contained several materials of different densities. Using the image stack histogram, an EM value was used to assign a label to each pixel of the stack (i.e. assigned to a region or unassigned if lying at the intersection of one or more regions). The computed threshold values between regions were selected where the inter-class entropies were maximised. These thresholds and estimated numbers of regions $(N)$ were then used as input for MRK to train $N-1$ semi-variograms to decide on the final region labelling of unclassified pixels. The above segmentation worked very well for soil cores with strong ring artefacts and beam-hardening artefacts such as TF, where other traditional methods failed.

The 3D characterisation of the porous architecture included the estimation of total macroporosity and the number of pores. The PSD was determined using the ImageJ plug-in XLib (http:// imagej.net/Xlib; Münch and Holzer 2008) by choosing the continuous PSD approach on the 3D segmented stack.

Following the MRK algorithm image stack segmentation, the $3 \mathrm{D}$ opening morphological operator with a kernel radius of 1 (ImageJ standard function) was applied to clear isolated (spurious) voxels. Using a combination of ImageJ plugins and custom-made macros, the following parameters were computed:

(1) Distribution of the pore skeleton characteristics: applying the ImageJ plugins Skeletonize3D and AnalyseSkeleton (Legland et al. 2016) to obtain pore skeleton start- and endpoints, multiple points and skeleton branch lengths;

(2) Percolating pore volume through the soil core: looking at the above information, finding all pores with skeleton startpoints on the first slice of the image stack and skeleton endpoints on the last slice of the image stack and summing all corresponding pore volumes (obtained via the 3D Object Counters ImageJ plugin);

(3) Pore size thickness: using the pore skeleton (from item 1), finding the largest 3D sphere fitting within the pore voxel volumes for each skeleton voxel and keeping the smallest value across the pore skeleton voxels (BoneJ; Doube et al. 2010);

(4) Tortuosity: datamining pore characteristics from item 1 to find the pore skeleton geodesic length and dividing it by the pore skeleton Euclidean length (as the straight distance between start- and end-points);

(5) Critical pore thickness: combining algorithms from items 2 and 3 and finding the smallest pore size thickness of the percolating pores;

(6) Specific surface and the Euler number: using the ImageJ plug-in MorphoLibJ (Legland et al. 2016);
(7) Fractal dimension: using the box counting algorithm available as a standard function in the ImageJ Analyse plugins.

\section{Mineralogical and chemical properties}

Soil $\mathrm{pH}$ was measured in suspensions of water and $1 \mathrm{M} \mathrm{KCl}$ (soil solution ratio 1:2.5, w/v). Total organic carbon and phosphate retention were analysed by total combustion (TOC-5050A, Shimadzu) and according to Blakemore et al. (1987) respectively.

Selective dissolutions of $\mathrm{Al}, \mathrm{Fe}$ and silicon ( $\mathrm{Si}$ ) compounds were carried out using three chemical reactants to extract amorphous or non-crystalline soil components. 'Active' or short-range-order $\mathrm{Al}, \mathrm{Fe}$ and $\mathrm{Si}$ compounds $\left(\mathrm{Al}_{\mathrm{ox}}, \mathrm{Fe}_{\mathrm{ox}}\right.$ and $\left.\mathrm{Si}_{\mathrm{ox}}\right)$ were extracted after shaking the soil with an ammonium oxalate solution $(0.2 \mathrm{M})$ buffered at $\mathrm{pH}$ 3. The $\mathrm{Al}, \mathrm{Fe}$ and $\mathrm{Si}$ complexed with organic matter $\left(\mathrm{Al}_{\mathrm{p}}, \mathrm{Fe}_{\mathrm{p}}\right.$ and $\left.\mathrm{Si}_{\mathrm{p}}\right)$ were extracted with sodium pyrophosphate solution following the method of Blakemore et al. (1987). The 'free' $\mathrm{Fe}_{\mathrm{d}}, \mathrm{Al}_{\mathrm{d}}$ and $\mathrm{Si}_{\mathrm{d}}$ compounds were extracted via a sodium citrate dithionite bicarbonate solution, following the method of Mehra and Jackson (1960). The Fe, $\mathrm{Al}$ and $\mathrm{Si}$ concentrations in supernatants were analysed using an atomic absorption spectrophotometer (SpectrAA 220, Varian).

\section{Statistical analysis}

We interpreted the differences between averages of the different physical and mineralogical characteristics by their respective least significant differences (1.s.d.) at the $95 \%$ confidence level $(P \leq 0.05)$ using ANOVA and testing for the homogeneity of variances (Levene's test for homogeneity of variance). The standard deviation of Brooks and Corey parameters were calculated based on the fitting of each measured SWRC. Standard errors of SWRC parameters were obtained with the LINEST function in Excel.

\section{Results and discussion}

\section{Main mineralogical and chemical properties}

The main soil physio-chemical properties of the different plots studied are presented in Table 1, and chemical dissolution results are shown in Table 2. According to FAO-ISRIC-ISSS (1998), Andosols must show the following properties: bulk density $<0.90 \mathrm{~g} \mathrm{~cm}^{-3}$ (Table 1 ), phosphate retention $\geq 70 \%$, volcanic glass content in the fine earth fraction $<10 \%$ and $\mathrm{Al}_{\mathrm{ox}}+$ $1 / 2 \mathrm{Fe}_{\mathrm{ox}} \geq 2 \%$ (Table 2). The soils from AM, AF and AMW complied with these guidelines and thus can be considered as Andosols. In contrast, TF and TT were described as Tepetates (J. Etchevers, pers. comm.), having a bulk density $>0.9 \mathrm{~g} \mathrm{~cm}^{-3}$ and $\mathrm{Al}_{\mathrm{ox}}+1 / 2 \mathrm{Fe}_{\mathrm{ox}}<2 \%$. The Tepetates studied here had high organic matter content (3.5-3.8\% organic carbon content) because they were sampled from a cultivated plot and a fallow plot with organic residue supplied over 10 years.

The contents of amorphous compounds (Table 2) varied significantly $(P<0.05)$ among plots with andic properties (AM, $\mathrm{AMW}$ and $\mathrm{AF}$ ). The lowest $\mathrm{Si}_{\mathrm{ox}}$ content for $\mathrm{AMW}$ indicates that this plot had less amorphous material. The $\mathrm{Al}_{\mathrm{p}} / \mathrm{Al}_{\mathrm{ox}}$ ratio was $<0.5$, indicating that the soils were allophanic (Parfitt and Saigusa 1985). Soil from AM had the highest allophane 
Table 1. Soil physico-chemical properties of the different plots studied

AM, Andosol under maize; AMW, Andosol under maize-wheat rotation; Top, depth 0-5 cm; and Sub, depth 30-35 cm; AF, Andosol under fallow; TF and TT for Tepetates under fallow and freshly tilled respectively; Org.C, organic carbon content; Total N, total nitrogen content; SSA, Specific surface area; -, not measured. Values in brackets are standard deviations. Values with different letters differ at $P<0.05$

\begin{tabular}{|c|c|c|c|c|c|c|c|c|c|}
\hline Plots & $\begin{array}{c}\text { Bulk density } \\
\left(\mathrm{Mg} \mathrm{m}^{-3}\right)\end{array}$ & Porosity & Clay (\%) & $\begin{array}{c}\text { Texture class } \\
\text { Silt }(\%)\end{array}$ & Sand $(\%)$ & $\mathrm{pH} \mathrm{KCl}$ & $\begin{array}{c}\text { Org.C } \\
(\%)\end{array}$ & $\begin{array}{c}\text { Total N } \\
(\%)\end{array}$ & $\begin{array}{c}\mathrm{SSA} \\
\left(\mathrm{m}^{2} \mathrm{~g}^{-1}\right)\end{array}$ \\
\hline AM-Top & $\begin{array}{l}0.77 \mathrm{~b} \\
(0.01)\end{array}$ & 0.71 & $\begin{array}{l}2.0 \mathrm{a} \\
(0.5)\end{array}$ & $\begin{array}{c}47.7 \mathrm{ab} \\
(11.7)\end{array}$ & $\begin{array}{l}50.3 \mathrm{bc} \\
(12.2)\end{array}$ & 5.56 & 4.68 & 0.4 & 133.7 \\
\hline AM-Sub & $\begin{array}{l}0.53 \mathrm{a} \\
(0.03)\end{array}$ & 0.80 & $\begin{array}{l}4.5 \mathrm{a} \\
(0.1)\end{array}$ & $\begin{array}{l}72.6 \mathrm{a} \\
(2.5)\end{array}$ & $\begin{array}{c}22.8 \mathrm{ab} \\
(2.5)\end{array}$ & 5.82 & 3.59 & 0.17 & 140.33 \\
\hline AMW-Top & $\begin{array}{l}0.86 \mathrm{~b} \\
(0.03)\end{array}$ & 0.68 & $\begin{array}{l}2.5 \mathrm{a} \\
(0.5)\end{array}$ & $\begin{array}{l}41.1 \mathrm{a} \\
(8.4)\end{array}$ & $\begin{array}{l}56.4 \mathrm{c} \\
(8.9)\end{array}$ & 5.30 & 4.93 & 0.34 & - \\
\hline AMW-Sub & $\begin{array}{l}0.51 \mathrm{a} \\
(0.01)\end{array}$ & 0.81 & $\begin{array}{c}2.7 \mathrm{ab} \\
(0.7)\end{array}$ & $\begin{array}{c}59.1 \mathrm{ab} \\
(10.4)\end{array}$ & $\begin{array}{l}38.1 \mathrm{ac} \\
(11.1)\end{array}$ & 5.73 & 4.46 & 0.21 & - \\
\hline $\mathrm{AF}$ & $\begin{array}{l}0.56 \mathrm{a} \\
(0.03)\end{array}$ & 0.79 & $\begin{array}{l}3.2 \mathrm{a} \\
(0.3)\end{array}$ & $\begin{array}{c}58.7 \mathrm{ab} \\
(6.9)\end{array}$ & $\begin{array}{c}38.0 \mathrm{ac} \\
(7.2)\end{array}$ & 5.4 & 4.87 & 0.47 & - \\
\hline $\mathrm{TF}$ & $\begin{array}{l}1.05 \mathrm{c} \\
(0.07)\end{array}$ & 0.60 & $\begin{array}{l}11.0 \mathrm{c} \\
(2.6)\end{array}$ & $\begin{array}{l}71.0 \mathrm{~b} \\
(9.7)\end{array}$ & $\begin{array}{l}18.1 \mathrm{a} \\
(12.4)\end{array}$ & 4.46 & 3.76 & 0.29 & - \\
\hline TT & $\begin{array}{l}1.02 \mathrm{c} \\
(0.02)\end{array}$ & 0.62 & $\begin{array}{l}7.1 \mathrm{~b} \\
(2.3)\end{array}$ & $\begin{array}{l}62.9 \mathrm{ab} \\
(14.8)\end{array}$ & $\begin{array}{l}30.1 \mathrm{ac} \\
(16.9)\end{array}$ & 4.36 & 3.48 & 0.18 & - \\
\hline
\end{tabular}

Table 2. Chemical selective dissolution of $\mathrm{Al}, \mathrm{Fe}$ and $\mathrm{Si}$ and mineralogy of the soil samples

AM, Andosol under maize; AMW, Andosol under maize-wheat rotation; Top, depth 0-5 cm; and Sub, depth 30-35 cm; AF, Andosol under fallow; TF and TT for Tepetates under fallow and freshly tilled respectively. $\mathrm{Al}_{\mathrm{ox}}, \mathrm{Fe}_{\mathrm{ox}}$ and $\mathrm{Si}_{\mathrm{ox}}$, active or shortrange-order $\mathrm{Al}, \mathrm{Fe}$ and $\mathrm{Si}$ compounds respectively; $\mathrm{Al}_{\mathrm{p}}$ and $\mathrm{Fe}_{\mathrm{p}}, \mathrm{Al}$ and $\mathrm{Fe}$ complexed with organic matter respectively; $\mathrm{Fe}_{\mathrm{d}}$, free $\mathrm{Fe}$. Values in brackets are standard deviations. Values with different letters differ at $P<0.05$

\begin{tabular}{|c|c|c|c|c|c|c|c|c|c|}
\hline $\begin{array}{c}\text { Plot and } \\
\text { depth }\end{array}$ & $\begin{array}{l}\mathrm{Si}_{\text {ox }} \\
(\%)\end{array}$ & $\begin{array}{l}\mathrm{Al}_{\mathrm{ox}} \\
(\%)\end{array}$ & $\begin{array}{l}\mathrm{Al}_{\mathrm{p}} \\
(\%)\end{array}$ & $\begin{array}{c}\mathrm{Al}_{\mathrm{ox}}+1 / 2 \mathrm{Fe}_{\mathrm{ox}} \\
(\%)\end{array}$ & $\begin{array}{c}\left(\mathrm{Al}_{\mathrm{ox}}-\mathrm{Al}_{\mathrm{p}}\right) / \\
\mathrm{Si}_{\mathrm{ox}}\end{array}$ & $\begin{array}{c}\text { Allophane } \mathrm{e}^{\mathrm{A}} \\
(\%)\end{array}$ & $\begin{array}{c}\text { Ferrihydrite }^{B} \\
(\%)\end{array}$ & $\begin{array}{l}\mathrm{Al}_{\mathrm{p}} / \\
\mathrm{Al}_{\mathrm{ox}}\end{array}$ & $\mathrm{Fe}_{\mathrm{d}}-\mathrm{Fe}_{\mathrm{p}}$ \\
\hline AM-Top & $\begin{array}{c}3.4 \mathrm{~cd} \\
(0.1)\end{array}$ & $\begin{array}{l}5.6 \mathrm{~b} \\
(0.0)\end{array}$ & $\begin{array}{c}0.08 \mathrm{~b} \\
(0.0)\end{array}$ & 6.3 & 1.6 & 24.0 & $\begin{array}{l}2.5 \mathrm{~b} \\
(0.3)\end{array}$ & 0.01 & $\begin{array}{l}1.23 \mathrm{ab} \\
(0.24)\end{array}$ \\
\hline AM-Sub & $\begin{array}{l}3.9 \mathrm{~d} \\
(0.1)\end{array}$ & $\begin{array}{l}6.1 \mathrm{~b} \\
(0.6)\end{array}$ & $\begin{array}{c}0.03 \mathrm{~b} \\
(0.0)\end{array}$ & 6.9 & 1.6 & 23.1 & $\begin{array}{l}2.7 \mathrm{~b} \\
(0.0)\end{array}$ & 0.01 & $\begin{array}{l}1.62 \mathrm{a} \\
(0.09)\end{array}$ \\
\hline AMW-Top & $\begin{array}{l}2.6 b \\
(0.1)\end{array}$ & $\begin{array}{l}4.9 b \\
(0.1)\end{array}$ & $\begin{array}{c}0.16 \mathrm{~b} \\
(0.0)\end{array}$ & 5.6 & 1.8 & 18.4 & $\begin{array}{l}2.4 \mathrm{~b} \\
(0.0)\end{array}$ & 0.03 & $\begin{array}{l}0.85 \mathrm{ce} \\
(0.06)\end{array}$ \\
\hline AMW-Sub & $\begin{array}{c}2.9 \mathrm{bc} \\
(0.2)\end{array}$ & $\begin{array}{l}5.3 b \\
(0.2)\end{array}$ & $\begin{array}{c}0.14 \mathrm{a} \\
(0.0)\end{array}$ & 5.9 & 1.7 & 20.8 & $\begin{array}{l}2.4 \mathrm{~b} \\
(0.1)\end{array}$ & 0.03 & $\begin{array}{l}1.36 \mathrm{e} \\
(0.13)\end{array}$ \\
\hline $\mathrm{AF}$ & $\begin{array}{l}3.3 \mathrm{c} \\
(0.2)\end{array}$ & $\begin{array}{l}5.3 b \\
(0.4)\end{array}$ & $\begin{array}{l}0.11 \mathrm{c} \\
(0.0)\end{array}$ & 6.2 & 1.6 & 19.9 & $\begin{array}{l}3.1 \mathrm{~b} \\
(0.6)\end{array}$ & 0.02 & $\begin{array}{c}1.03 \mathrm{bcd} \\
(0.04)\end{array}$ \\
\hline TF & $\begin{array}{l}0.5 \mathrm{a} \\
(0.0)\end{array}$ & $\begin{array}{l}1.4 \mathrm{a} \\
(0.0)\end{array}$ & $\begin{array}{c}0.09 \mathrm{~d} \\
(0.0)\end{array}$ & 0.6 & 2.5 & 5.1 & $\begin{array}{l}0.9 \mathrm{a} \\
(0.0)\end{array}$ & 0.06 & $\begin{array}{c}0.57 \mathrm{ac} \\
(0.007)\end{array}$ \\
\hline TT & $\begin{array}{l}0.7 \mathrm{a} \\
(0.0)\end{array}$ & $\begin{array}{l}1.7 \mathrm{a} \\
(0.0)\end{array}$ & $\begin{array}{c}0.08 \mathrm{~d} \\
(0.0)\end{array}$ & 0.6 & 2.4 & 5.4 & $\begin{array}{l}1.2 \mathrm{a} \\
(0.1)\end{array}$ & 0.05 & $\begin{array}{c}0.76 \mathrm{de} \\
(0.0)\end{array}$ \\
\hline
\end{tabular}

\footnotetext{
${ }^{\mathrm{A}}$ Allophane $=\mathrm{Si}_{\mathrm{ox}} \times$ factor; factor depends on $\left(\mathrm{Al}_{\mathrm{ox}}-\mathrm{Al}_{\mathrm{p}}\right) / \mathrm{Si}_{\mathrm{ox}}$ relation $($ Parfitt 1990)
}

${ }^{\mathrm{B}}$ Ferrihydrite $=1.7 \times \mathrm{Fe}_{\mathrm{ox}}$ (Childs et al. 1991).

content $(\sim 23 \%, P<0.05)$, whereas allophane contents in the other plots were $\sim 19 \%$. These differences could be due to land use or to volcanic ejecta from different origins. The iron oxide contents in the three plots were $\sim 1.3 \%\left(\mathrm{Fe}_{\mathrm{d}}-\mathrm{Fe}_{\mathrm{p}}\right.$; Gunjigake and Wada 1981), mainly in a crystalline form. The chemical selective dissolution of $\mathrm{Fe}$ indicated different $\mathrm{Fe}$ weathering products within the AM and AMW profiles. The different degrees of alteration supported the hypothesis that these profiles were formed by the accumulation of layers of volcanic ash transported over time from the upper to the lower parts of the sequence (Rodriguez Tapia et al. 1999). In the three plots (AF, AM and AMW), the high contents of $\mathrm{Si}_{\mathrm{ox}}$ $(2.6-3.9 \%)$ and values of $\left(\mathrm{Al}_{\mathrm{ox}}-\mathrm{Al}_{\mathrm{p}}\right) / \mathrm{Si}_{\mathrm{ox}}$ of $1.6-1.8 \%$ indicated that the soils contained both types of allophanes rich in silica and Al (Parfitt 1980). Ferrihydrite was present at $\sim 2.5 \%$ in the three plots.

The specific surface area (SSA) of the ploughed AM varied from $134 \mathrm{~m}^{2} \mathrm{~g}^{-1}$ in the topsoil to $140 \mathrm{~m}^{2} \mathrm{~g}^{-1}$ in the subsoil (Table 1). These values were higher than those found by Hepper et al. (2006) for Argentinian loess soils with volcanic ash 
deposits. As found by the previous authors and Bartoli et al. (2007), SSA increased with increasing clay amounts and with decreasing organic matter.

\section{Static physical properties}

As described in Prado et al. (2007), the soil had a granular micro (fluffy) structure in the upper layer, which changed to a subangular blocky structure in deeper horizons (below $20 \mathrm{~cm}$ ). The bulk density of the cultivated Andosols (AM and AMW) decreased with depth and was higher in fallow than tilled plots $(P<0.05$; Table 1$)$. Allophane is one of the most important non-crystalline materials contributing to the low bulk density of Andosols through the development of its porous structure (Nanzyo et al. 1993b).

All studied soils were silt-loam in texture. Tepetates had higher clay and silt contents $(P<0.05)$ compared with the Andosols. Comparison of the surface horizons showed that ploughing soil (comparing AMW-Top and AM-Top with AF, and TT with TF) led to an increase in the sand fraction $(P<0.05)$. The same observation was made by comparing the surface and deep horizons from the same profile. Indeed, ploughing exposes the soil surface to drying processes, especially in the dry season, leading to irreversible formation of aggregates from the colloidal fraction (Nanzyo 2002). The decrease in fine fraction could also be due to soil surface or internal erosion.

\section{Water retention and hydrodynamic parameters}

The SWRCs for all soils are presented Fig. 2. The parameters obtained from the fit to the Brooks and Corey model (Eqn 1) are shown in Table 3, with coefficients of determination $\left(R^{2}\right)>0.9$. The standard deviation for Brooks and Corey parameters (Table 3) demonstrates good repeatability of experimental water content values for AMW (Top and Sub), TF, TT and AM-Sub. The large variation of the experimental values for AM-Top and AF, however, led to a large uncertainty in the fitted values for $\mathrm{AM}-\mathrm{Top}$ and $\mathrm{AF}$, especially regarding to shape parameter $\lambda$ and the residual water content (AM-Top). The values of saturated water content and air-entry pressure, however, showed little deviation. All topsoils from the Andosols plots (AM, AMW and AF) had high values of saturated water content, but Tepetates (TT and TF) had saturated water content in the lower range. All SWRC behaved comparably to those of clay loam or silt-loam textured soils (reference soils in SWRC-fit software (Seki 2007) from the UNSODA database: clay loam is UNSODA 3033 and silty loam is USODA 2760). The AM and AF had higher water retention (i.e. water content values at low pressure head, Fig. 2) than TT, TF and AMW. No differences were observed between TT and TF: indeed, the water content

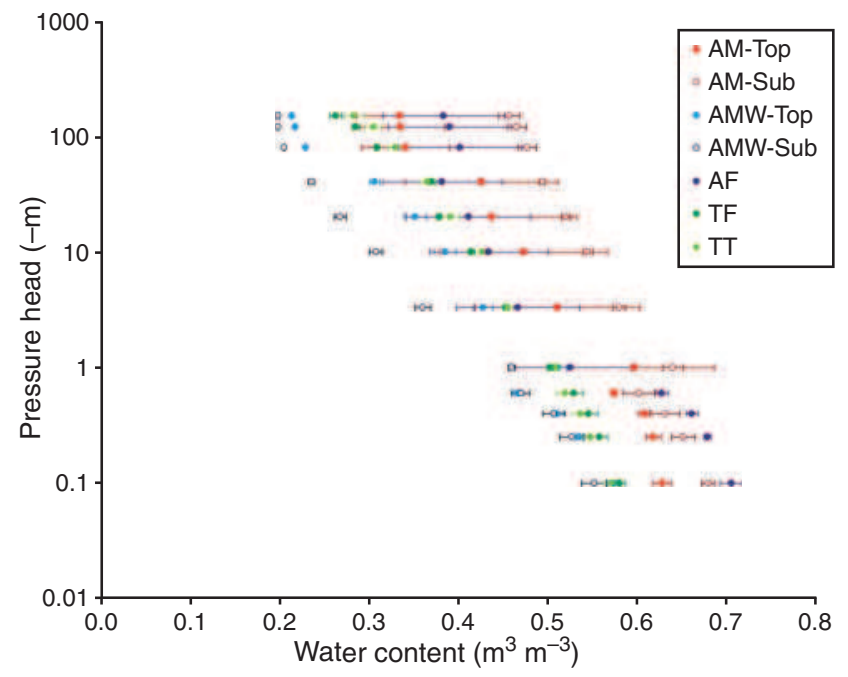

Fig. 2. Water retention curve for each plot studied, error bars represent standard deviation. AM, Andosol under maize; AMW, Andosol under maize-wheat rotation; Top, depth 0-5 cm; Sub, depth 30-35 cm; AF, Andosol under fallow; and TF and TT, Tepetates under fallow and freshly tilled respectively.

Table 3. Hydraulic parameters for the water retention and hydraulic conductivity curves

AM, Andosol under maize; AMW, Andosol under maize-wheat rotation; Top, depth 0-5 cm; and Sub, depth 30-35 cm; AF, Andosol under fallow; TF and TT for Tepetates under fallow and freshly tilled respectively; $\theta_{\mathrm{s}}$ and $\theta_{\mathrm{r}}$, saturated and residual water contents, respectively; $h_{\mathrm{c}}$, air-entry pressure value, $\lambda$, soil-dependent shape parameter; $K_{\mathrm{s}}$, saturated hydraulic conductivity; $\alpha$, soil-dependent parameter; $\lambda_{\mathrm{m}}$, effective mean pore radius. Values in brackets are standard deviations

\begin{tabular}{|c|c|c|c|c|c|c|c|c|c|}
\hline \multirow[b]{2}{*}{ Plots and depth } & \multicolumn{5}{|c|}{ Water retention curve: Brooks and Corey parameters } & \multicolumn{4}{|c|}{ Hydraulic conductivity curve: Gardner parameters } \\
\hline & $\theta_{\mathrm{r}}$ & $\theta_{\mathrm{s}}$ & $h_{\mathrm{c}}(\mathrm{m})$ & $\lambda$ & $R^{2}$ & $K_{\mathrm{s}}\left(\mathrm{m} \mathrm{s}^{-1}\right)$ & $\alpha\left(\mathrm{m}^{-1}\right)$ & $R^{2}$ & $\lambda_{\mathrm{m}}(\mathrm{m})$ \\
\hline AM-Top & $\begin{array}{c}3 \times 10^{-5} \\
(0.10)\end{array}$ & $\begin{array}{c}0.64 \\
(0.02)\end{array}$ & $\begin{array}{l}0.25 \\
(0.04)\end{array}$ & $\begin{array}{c}0.09 \\
(0.15)\end{array}$ & 0.97 & $\begin{array}{c}1.8 \times 10^{-5} \\
\left(4.4 \times 10^{-6}\right)\end{array}$ & $\begin{array}{c}7.6 \\
(1.8)\end{array}$ & 0.78 & $\begin{array}{r}5.6 \times 10^{-5} \\
\left(1.3 \times 10^{-5}\right)\end{array}$ \\
\hline AM-Sub & $\begin{array}{c}2 \times 10^{-6} \\
\left(6 \times 10^{-5}\right)\end{array}$ & $\begin{array}{c}0.71 \\
(0.01)\end{array}$ & $\begin{array}{c}0.044 \\
(0.002)\end{array}$ & $\begin{array}{c}0.052 \\
(0.0002)\end{array}$ & 0.98 & $\begin{array}{r}1.9 \times 10^{-5} \\
\left(5.4 \times 10^{-6}\right)\end{array}$ & $\begin{array}{c}9.4 \\
(2.4)\end{array}$ & 0.89 & $\begin{array}{r}7.0 \times 10^{-5} \\
\left(1.7 \times 10^{-5}\right)\end{array}$ \\
\hline AMW-Top & $\begin{array}{r}1 \times 10^{-5} \\
\left(2 \times 10^{-5}\right)\end{array}$ & $\begin{array}{c}0.62 \\
(0.01)\end{array}$ & $\begin{array}{c}0.082 \\
(0.005)\end{array}$ & $\begin{array}{c}0.12 \\
(0.003)\end{array}$ & 0.95 & $\begin{array}{r}9.3 \times 10^{-6} \\
\left(1.9 \times 10^{-6}\right)\end{array}$ & $\begin{array}{c}5.9 \\
(1.2)\end{array}$ & 0.65 & $\begin{array}{r}4.3 \times 10^{-5} \\
\left(9.1 \times 10^{-6}\right)\end{array}$ \\
\hline AMW-Sub & $\begin{array}{r}5 \times 10^{-7} \\
\left(2 \times 10^{-6}\right)\end{array}$ & $\begin{array}{c}0.57 \\
(0.01)\end{array}$ & $\begin{array}{c}0.19 \\
(0.002)\end{array}$ & $\begin{array}{c}0.16 \\
(0.0007)\end{array}$ & 0.98 & $\begin{array}{c}5.2 \times 10^{-6} \\
\left(3.4 \times 10^{-6}\right)\end{array}$ & $\begin{array}{c}4.9 \\
(3.3)\end{array}$ & 0.36 & $\begin{array}{r}3.7 \times 10^{-5} \\
\left(2.4 \times 10^{-5}\right)\end{array}$ \\
\hline $\mathrm{AF}$ & $\begin{array}{c}0.4 \\
(0.05)\end{array}$ & $\begin{array}{c}0.69 \\
(0.02)\end{array}$ & $\begin{array}{c}0.34 \\
(0.10)\end{array}$ & $\begin{array}{c}0.58 \\
(0.21)\end{array}$ & 0.99 & $\begin{array}{r}5.0 \times 10^{-6} \\
\left(4.5 \times 10^{-6}\right)\end{array}$ & $\begin{array}{c}8.8 \\
(7.0)\end{array}$ & 0.21 & $\begin{array}{c}6.5 \times 10^{-5} \\
\left(5.2 \times 10^{-5}\right)\end{array}$ \\
\hline $\mathrm{TF}$ & $\begin{array}{c}6 \times 10^{-6} \\
\left(3 \times 10^{-6}\right)\end{array}$ & $\begin{array}{c}0.57 \\
(0.006)\end{array}$ & $\begin{array}{l}0.28 \\
(0.02)\end{array}$ & $\begin{array}{c}0.11 \\
(0.002)\end{array}$ & 0.98 & $\begin{array}{c}3.7 \times 10^{-6} \\
\left(6.1 \times 10^{-7}\right)\end{array}$ & $\begin{array}{c}7.9 \\
(1.2)\end{array}$ & 0.81 & $\begin{array}{r}5.8 \times 10^{-5} \\
\left(8.8 \times 10^{-6}\right)\end{array}$ \\
\hline $\mathrm{TT}$ & $\begin{array}{c}5 \times 10^{-6} \\
\left(2 \times 10^{-6}\right)\end{array}$ & $\begin{array}{c}0.57 \\
(0.009)\end{array}$ & $\begin{array}{c}0.29 \\
(0.01)\end{array}$ & $\begin{array}{c}0.10 \\
(0.002)\end{array}$ & 0.98 & - & - & - & \\
\hline
\end{tabular}


differences between both plots were $<0.02$ considering all pressure heads taken together (Fig. 2), and there was no significant difference in fitted Brooks and Corey parameters. The differences between AM, AF and AMW could be explained by differences in land use or by the different contents of amorphous compounds. When comparing topsoil and subsoil SWRC, opposing behaviours were observed for AMW and AM plots. Indeed, for AMW, the SWRCs were similar, except in the medium range of matric suction. In contrast, for the AM plot, subsoil SWRC had a higher water retention capacity especially at high suctions $(P<0.05)$. This high water retention capacity for AM-Sub was observed by Prado et al. (2007), with water content of AM-Sub always higher than that of AM-Top even after heavy rainfall $\left(>50 \mathrm{~mm} \mathrm{day}^{-1}\right)$. This could be explained by the allophane content; the water content at 150 -m matric suction for Andosols (AM, AWM and AF) was positively related to $\mathrm{Si}_{\text {ox }}$ content $\left(R^{2}=0.87\right)$. Drying provokes the decrease of hygroscopic water, leading to a definitive decrease in water retention capacity. Non-crystalline materials such as allophanes make the greatest contribution to these irreversible changes (Shoji et al. 1993). Buytaert et al. (2002) studied the effect of soil use on the hydrological properties of volcanic soils from Ecuador and concluded that the loss in water retention capacity was irreversible. For Andosols, it was demonstrated that hygroscopic water was correlated with $\mathrm{Si}_{\text {ox }}$ and $\mathrm{Al}_{\text {ox }}$ (Nanzyo 2002). Calculated air-entry suctions were low (4.4 and $8.2 \mathrm{~cm}$ respectively) for AM-Sub and AMW-Top. It should be noted, however, that these values are below those from the highest imposed pressure head of $h=-0.1 \mathrm{~m}$, and the results should thus be considered with caution.

During the field measurement of hydraulic conductivity, the flux under the disc infiltrometer did not vary much with the pressure head (Fig. 3a), resulting in high uncertainty in the determination of the unsaturated hydraulic conductivity when fitted to the Wooding equation (Eqn 2). This is likely due to the soils remaining close to saturation for pressure heads between 0 and $-0.1 \mathrm{~m}$, as suggested by the air-entry pressures computed from the Brooks and Corey model (Table 3). More specifically, the variation of the flux with the pressure head (Fig. $3 a$ ) in the studied range was of a similar order of magnitude to the variability of the measurement. The variability was especially large for AF and AMW-Sub, explaining the low $R^{2}$ of the fitting with the Gardner equation. Müller et al. (2018) also found lower variations in unsaturated hydraulic conductivity (between -0.7 and $-0.1 \mathrm{~m}$ pressure head) and higher values of unsaturated hydraulic conductivities in Andosol (silt-loam) than in Gleysol (clay loam). The soils showed $K_{\mathrm{s}}$ in the range of $0.37 \times 10^{-5}$ to $1.90 \times 10^{-5} \mathrm{~m} \mathrm{~s}^{-1}$, usually associated with sandy-loam and silty-loam textures; it was higher in AM-Top and -Sub and AMW-Top and lower in AMW-Sub, AF, TF and TT (Table 3). The values of unsaturated conductivities followed the same order when measured at $\mathrm{h}=-0.1$ and $-0.01 \mathrm{~m}$. The indurated soils showed high hydraulic conductivities compared with other studies (Navarro and Zebrowzki 1992), probably due to their high organic carbon content (3.6\% on average). The macropore classes (Fig. 3b) participating in the flow near saturation (under the tension disc-infiltrometer) showed that the most important class was pores $<100 \mu \mathrm{m}$ in diameter. (a)

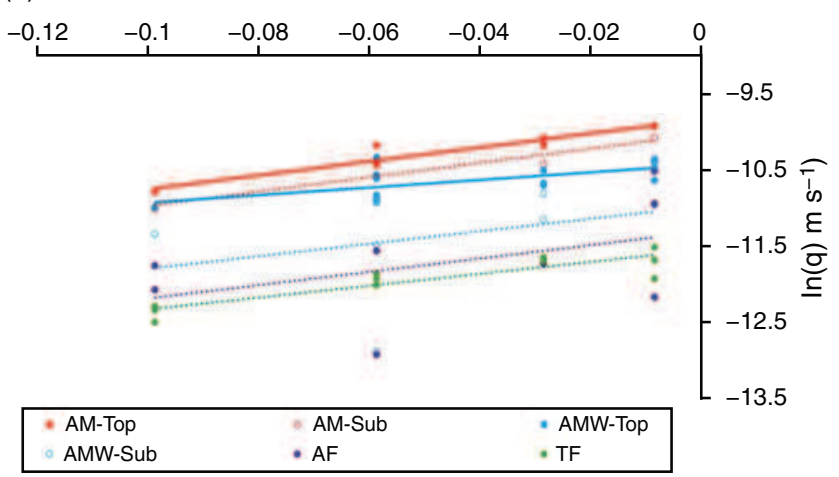

(b)

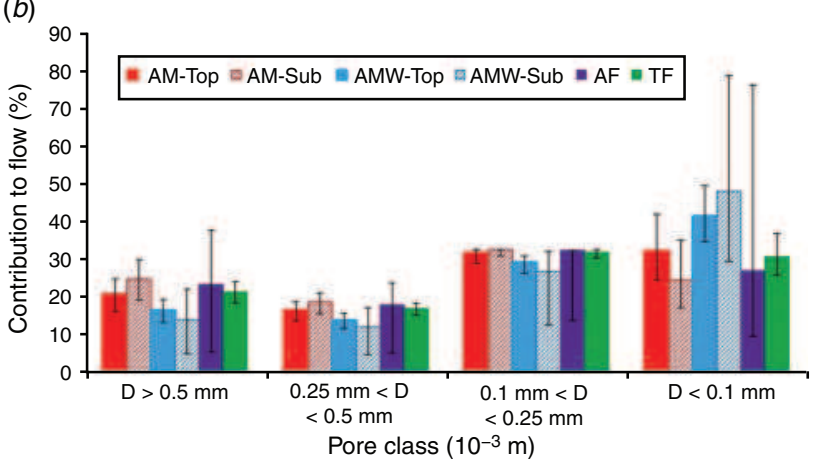

Fig. 3. (a) Relationship between flux $(\ln (q))$ under the infiltrometer and pressure head $(h)$ for each plot. Marks are experimental points, lines are the fit based on Wooding equations (plain line for Top and dotted line for Sub). (b) Contribution of each pore class to flow under the tension discinfiltrometer for each plot studied. AM, Andosol under maize; AMW, Andosol under maize-wheat rotation; Top, depth $0-5 \mathrm{~cm}$; Sub, depth 30-35 cm; AF, Andosol under fallow; and TF, Tepetates under fallow.

Indeed, the PSD (see below) showed that pores $>100 \mu \mathrm{m}$ represented only a few percent of the total porous volume. On average, pore classes contributing to the flow were comparable for AM-Top, AM-Sub, AF and TF, while there were more pores $<100 \mu \mathrm{m}$ participating in the flow for AMWTop. The $\lambda_{\mathrm{m}}$ values for AM, AF and TF (average $62 \mu \mathrm{m}$ ) were similar, indicating that tillage had no significant effect on this parameter. The $\lambda_{m}$ values were in the lower range of those reported in White and Sully (1987) and were close to values for clay soils, although White and Sully (1987) found no significant correlation between soil texture and $\lambda_{\mathrm{m}}$. The values for AMWTop demonstrate a lower $\lambda_{\mathrm{m}}$ (Table 3 ) compared with the other plots, showing a stronger role of capillary forces (AnguloJaramillo et al. 2000).

\section{Porosity and PSD}

Pore volume and PSD were analysed with different techniques investigating different pore sizes (Table 4 and Fig. 4). Gas adsorption was used for pores $<18.5 \mathrm{~nm}$, MIP for $>8 \mathrm{~nm}$ and SWRC for $>200 \mathrm{~nm}$. The X-ray tomography measured pores $>2$ voxels $(>88 \mu \mathrm{m})$. Consequently, we could compare SWRC and MIP for pores $>200 \mathrm{~nm}$ and SWRC, MIP and X-ray tomography for pores $>100 \mu \mathrm{m}$. Methodologically, the gas adsorption, SWRC and MIP techniques are based on the 
invasion or intrusion of gas or liquid in the accessible porous system and the capillary theory. The MIP and SWRC are analogous methods, MIP uses air as the wetting fluid, corresponding to the water, and mercury as the non-wetting fluid, corresponding to the air in the water-air system, and the results between the two techniques can differ due to other influences such as contact angles, swelling clays and intrusion rather than desaturation processes (Nimmo 2004). These techniques are subject to the 'ink bottle effect' and depend on the pore connectivity and access to external surfaces (Dal Ferro et al. 2012). Similarly, the gas adsorption method only recognises the pore neck, because the bottle pore size is usually greater than the nitrogen condensation limit (Zong et al. 2015). However, at the scan resolution, X-ray tomography identifies connected as well as isolated pores in addition to their body size and shape. Unfortunately, this method is confounded by other issues, such as subjectivity in threshold operations and manipulation of tomography images (Baveye et al. 2018). In the present case, the 3D PSD obtained through image analysis of the X-ray tomography corresponded to the continuous approach described by Münch and Holzer (2008). In this method, pores are filled with spheres of different radii, allowing evaluation of PSD.

Table 4. Ranges of visible porosity by the different techniques AM, Andosol under maize; Top, depth $0-5 \mathrm{~cm}$; and Sub, depth $30-35 \mathrm{~cm}$; MIP, mercury intrusion porosimetry; SWRC, soil water retention curve; $\mathrm{HK}+\mathrm{BJH}$, gas adsorption; $\mu \mathrm{CT}, \mathrm{X}$-ray computed tomography

\begin{tabular}{lcccc}
\hline Method & $\begin{array}{c}\text { Proportion of porosity } \\
\text { 'visible' (\%) } \\
\text { AM-Top }\end{array}$ & $\begin{array}{c}\text { Minimum } \\
\text { pore } \\
\text { size } \\
\text { 'visible' }\end{array}$ & $\begin{array}{c}\text { Maximum } \\
\text { pore size } \\
\text { 'visible' } \\
(\mathrm{nm})\end{array}$ \\
\hline MIP & 79.9 & 76.4 & $6.1 \mathrm{~nm}$ & - \\
SWRC & 48.5 & 36.1 & $200 \mathrm{~nm}$ & - \\
HK + BJH & 30.2 & 40.0 & $0.4 \mathrm{~nm}$ & 18.5 \\
$\mu \mathrm{CT}$ & 3.3 & 5.6 & $88 \mu \mathrm{m}$ & - \\
\hline
\end{tabular}

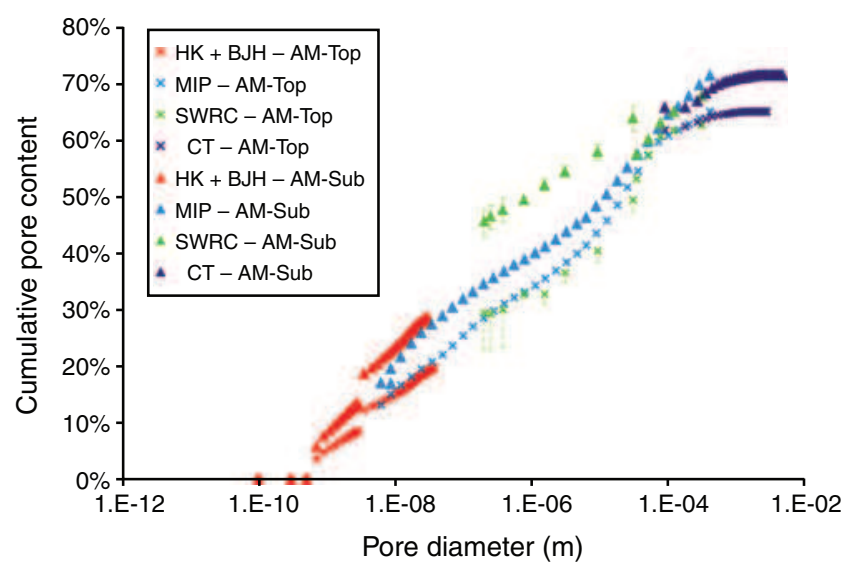

Fig. 4. Cumulative pore size distribution for AM plot (Andosol under maize) comparing the different techniques. HK + BJH, gas adsorption; SWRC, soil water retention curve; MIP, mercury intrusion porosimetry; $\mu \mathrm{CT}$, X-ray tomography; Top, depth $0-5 \mathrm{~cm}$; and Sub, depth $30-35 \mathrm{~cm}$. Error bars are presented for the soil water retention curve data (SWRC).
Total pore volume, estimated via bulk density determination and assuming a particle density of $2.65 \mathrm{~g} \mathrm{~m}^{-3}$ (Nanzyo 2002), varied between treatments, ranging from a minimum of $0.60 \mathrm{~cm}^{3} \mathrm{~cm}^{-3}$ in TF to a maximum of $0.81 \mathrm{~cm}^{3} \mathrm{~cm}^{-3}$ in the lower horizon of AM-Sub and AMW-Sub (Table 1). Bulk density determined by MIP (only for AM-Top and AM-Sub) was $15-20 \%$ higher. Several factors could explain this discrepancy: MIP is performed on aggregates excluding inter-aggregate macropores or MIP only measures pore $>6 \mathrm{~nm}$. However, the macroporosity (pores $>400 \mu \mathrm{m}$ ) obtained by X-ray tomography represented only $1 \%$ of the total porosity for AM-Top and $2 \%$ of AM-Sub, so we attributed the porosity discrepancy between SWRC and MIP to the nanoporosity.

Consequently, MIP results were re-computed considering a maximum pore volume based on the saturated water content obtained from the SWRC, which is why the cumulative PSD reached the same cumulative pore content at the highest pore diameters for SWRC and MIP. A similar approach was used for data based on X-ray tomography. For AM-Top and AM-Sub soils, the different techniques resulted in similar cumulative PSDs, and only the pores determined via SWRC for AM-Sub overestimated the pores between $3 \times 10^{-5}$ and $2 \times 10^{-7} \mathrm{~m}$ compared with the MIP technique. When comparing the AM-Top to AM-Sub PSDs, AM-Sub had a larger volume of pores for all pore diameters, especially for pores of $10^{-8}$ to $10^{-5} \mathrm{~m}$ and $>10^{-4} \mathrm{~m}$. Other studies have demonstrated the effect of ploughing on the decrease of macropore volume (e.g. Galdos et al. 2019).

\section{Soil 3D architectural parameters}

Pore architecture for pores $>4$ voxels was only studied for AMTop, AM-Sub and TF (Table 5). Considering the resolution of the X-ray tomography (1 voxel or $44 \mu \mathrm{m}$ ), only large pores (referred to as macroporosity) were observed. Pore volume varied within 5, 7 and $11 \%$ of the total porosity for AMTop, AM-Sub and TF respectively. Macropore density was higher for AM-Top, indicating that this ploughed horizon had a larger number of isolated pores of smaller volume. However, these isolated pores, despite being numerous, corresponded to a small overall volume, and the total macroporosity of AM-Top was the lowest (3.3\%). Müller et al. (2018) found that Andosols

Table 5. Macropore parameters obtained by X-Ray tomography images analyses

AM, Andosol under maize; Top, depth $0-5 \mathrm{~cm}$; and Sub, depth $30-35 \mathrm{~cm}$; TF, Tepetates under fallow. Values in brackets are standard deviations

\begin{tabular}{lccc}
\hline Parameters & AM-Top & AM-Sub & TF \\
\hline Total macroporosity & 0.033 & 0.056 & 0.067 \\
Percolating macroporosity & 0.020 & 0.029 & 0.045 \\
D50 - median macropore diameter $(\mu \mathrm{m})$ & 304 & 386 & 451 \\
Macropore density (number $\mathrm{mm}^{-3}$ ) & 21.18 & 6.31 & 2.91 \\
Average tortuosity & 1.28 & 1.33 & 1.26 \\
& $(0.42)$ & $(0.67)$ & $(0.31)$ \\
Fractal dimension & 2.57 & 2.50 & 2.14 \\
& $(0.99)$ & $(0.99)$ & $(0.98)$ \\
Critical pore thickness $(\mathrm{mm})$ & 0.8 & 0.1 & 0.9 \\
Total Euler number & 33542 & 17071 & 9639 \\
Euler number of the percolating pore & -5782 & -1852 & -1987 \\
\hline
\end{tabular}



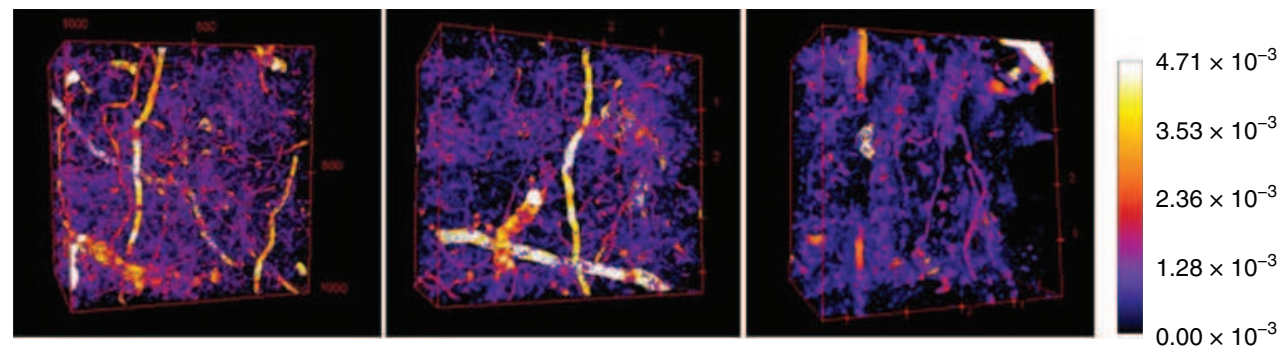

Fig. 5. The 3D pore thickness for AM-Top, AM-Sub (Andosol under maize) and TF (Tepetates under fallow). Top, depth 0-5 cm; and Sub, depth 30-35 cm. Colour bar indicates the pore thickness (m).

had a more homogeneous macropore network, a higher macropore density and a smaller average mean macropore diameter than Gleysols. Large fractal dimension values indicated that the macropores were more space-filling in the image. The fractal dimension was higher for AM columns than for TF, comparable to the mass fraction dimension calculated by Jarvis et al. (2017) (2.1 and 2.5) and larger than the values reported by Cercioglu et al. (2018) (1.76-1.96), both for siltloam soils. Tortuosity did not differ among the three plots, and had values below those reported by Müller et al. (2018). The 3D images representing the local thickness (Fig. 5) showed rather tubular, non-tortuous pores for AM, with root-like shapes and some non-tubular, large, complex pores with undefined shapes in TF. The AM-Top had the highest positive Euler number value, related to the large number of isolated small macropores mentioned earlier. Prado et al. (2011) studied the same plots and found preferential flow in AM-Sub, but none in AM-Top. The effect of tillage on the pore connectivity of volcanic ash soils was also noted by Ordóñez et al. (2018), who showed that tilled soils had less connectivity between pores compared with untilled soils. Galdos et al. (2019) found that conventional tillage in Brazilian clay soils increased the number of pores but reduced the macroporosity and the connectivity compared with zero tillage.

Each of these soil cores had one percolating pore, representing $60.6,51.8$ and $67.2 \%$ of the visible macroporosity via X-ray tomography for AM-Top, AM-Sub and TF respectively. The critical thickness of this unique percolating pore per core was 0.8 , 0.9 and $0.1 \mathrm{~mm}$ for AM-Top, TF and AM-Sub respectively. The Euler characteristic was about twice as negative for AM-Top compared with AM-Sub and roughly four times more negative compared with TF. Thus, the AM-Top-percolating pore had more connections that were redundant and less-enclosed cavities than the TF and AM-Sub percolating pores (Vogel 2002).

Although too few cores were studied to allow statistical analysis, we found relationships between structural characteristics and soil parameters similar to other studies. The ratios of $K(h) / K_{\mathrm{s}}$ for $h=-0.1$ and $-0.01 \mathrm{~m}$ were negatively related to the critical pore thickness $\left(R^{2}=0.88\right.$ and 0.87 respectively). Considering that the ratio $K(h) / K_{\mathrm{s}}$ can be related to $\alpha$ and $\lambda_{\mathrm{m}}$, following Eqns 3 and 4 , similar relationships were obtained for these parameters. When a soil desaturates, the largest pores are the first to be filled with air and are therefore the first to cease to participate in the water flow. Consequently, a soil with a higher critical pore thickness will de-saturate at a lower suction, disconnecting the macropores and thus diminishing the near-saturated hydraulic conductivity. Near-saturated hydraulic conductivity $K(h)$ was negatively correlated with percolating macroporosity $\left(R^{2}=0.83\right.$ for $h=-0.01 \mathrm{~m}$ and $R^{2}=0.67$ for $h=-0.1 \mathrm{~m}$ ), similar to the result of Müller et al. (2018), who found that, although the studied Andosols had the smallest imaged macroporosity, they had significantly higher near-saturated hydraulic conductivities. Their conclusion was that, in Andosols, pores not visible at the X-ray tomography resolution play an important role in hydraulic unsaturated conductivity.

\section{Conclusion}

Our study combined field and laboratory macroscopic and microscopic analyses of volcanic ash soils, with the aim to improve our knowledge of the physical properties of these unique soils and of the effect of land use on these properties. The different techniques employed were complementary to give a complete image of the PSD and macropore architecture. The X-ray tomography offered new insights into the connectivity, size and shape of volcanic ash soil macropores, showing that macropores in the Andosol had a root-like shape with low tortuosity. The different agricultural practices and the two soils studied showed significant differences in their PSD, macropore morphological parameters and hydrodynamic properties although the Tepetates were probably not representative of indurated soils because of their high content of organic carbon. Tillage had an impact on the Andosol porous network and pore size of volcanic soils but not on its hydrodynamic properties, while the rotation of maize and wheat compared with maize alone also affected water retention capacity, hydraulic conductivity and pore sizes conducting the flow. Considering the results of this study, recommendations for sustainable agricultural practices on Andosol are to apply minimum tillage, reduce periods when the soil is bare and not to apply maize-wheat rotation but use rotations of maize alone with fallow periods allowing natural plant growth.

Knowledge on volcanic soil macropore network should be improved by studying several soil cores of the same plot using $\mathrm{X}$-ray tomography and investigating more agricultural practices. The impact of agriculture practices on volcanic soil hydrodynamic properties needs to be confirmed at larger scales by employing different measuring tools such as geophysics and lysimeters.

\section{Conflicts of interest}

The authors declare no conflicts of interest. 


\section{Acknowledgements}

This project received funding from the European Union's Horizon 2020 research and innovation program under grant agreement No. 645717. The authors thank Lucy Mora for the statistical analyses of the experimental data.

\section{References}

Aguilera HN (1963) Algunas consideraciones, características, génesis y clasificación de los suelos de Ando. In 'Proceedings of the 1st National Congress of Soil Science'. pp. 233-247. (Sociedad Mexicana de la Ciencia del Suelo D.F.: Mexico)

Angulo-Jaramillo A, Vandervaere JP, Roullier S, Thony JL, Vauclin M (2000) Field measurement of soil surface hydraulic properties by disc and ring infiltrometers: A review and recent developments. Soil \& Tillage Research 55(1-2), 1-29. doi:10.1016/S0167-1987(00) 00098-2

Arnalds O, Stahr K (2004) Volcanic soil resources: occurrence, development, and properties Catena 56(1-3), 1-2. doi:10.1016/ j.catena.2003.10.001

Azhar M, Chang X, Debes J, Delmas P, Duwig C, Dal Ferro N, Gee T, Marquez Flores J (2019) Advantages of multi-region kriging over bi-region techniques for computed tomography-scan segmentation. Soil Research 57, 521-534. doi:10.1071/SR18294

Barrett EP, Joyner LG, Halenda PP (1951) The determination of pore volume and area distributions in porous substances. I. Computations from nitrogen isotherms. Journal of the American Chemical Society $\mathbf{7 3}$ (1), 373-380. doi:10.1021/ja01145a126

Bartoli F, Poulenard J, Schouller BE (2007) Influence of allophane and organic matter contents on surface properties of Andosols. European Journal of Soil Science 58(2), 450-464. doi:10.1111/j.1365-2389. 2007.00899.x

Basile A, Coppola A, De Mascellis R, Mele G, Terribile F (2007) A comparative analysis of the pore system in volcanic soils by means of water-retention measurements and image analysis. In 'Soils of volcanic regions in Europe'. (Eds Ó Arnalds, H Óskarsson, F Bartoli, P Buurman, G Stoops, E García-Rodeja) pp. 493-513. (Springer: Berlin, Heidelberg)

Baveye PC, Otten W, Kravchenko A, Balseiro Romero M, Beckers É, Chalhoub M, Darnault C, Eickhorst T, Garnier P, Hapca S, Kiranyaz S, Monga O, Mueller CW, Nunan N, Pot V, Schlüter S, Schmidt H, Vogel HJ (2018) Emergent properties of microbial activity in heterogeneous soil microenvironments: different research approaches are slowly converging, yet major challenges remain. Frontiers in Microbiology 8, 1929. doi:10.3389/fmicb.2018.01929

Blakemore LC, Searle PL, Daly BK (1987) Methods for chemical analysis of soils. New Zealand Soil Bureau Scientific Report 80, New Zealand Soil Bureau Lower Hutt, New Zealand.

Brooks R, Corey T (1964) Hydraulic properties of porous media. Hydrology Papers, Colorado State University 24, Colorado State University, Fort Collins, CO, USA.

Buurman P, van Doesburg JDJ (2007) Laser-diffraction grain-size analyses of reference profiles. In 'Soils of volcanic regions in Europe'. (Eds Ó Arnalds, H Óskarsson, F Bartoli, P Buurman, G Stoops, E GarcíaRodeja) pp. 453-468. (Springer: Berlin, Heidelberg).

Buurman P, De Boer K, Pape T (1997) Laser diffraction grain-size characteristics of Andisols in perhumid Costa Rica: the aggregate size of allophane. Geoderma 78(1-2), 71-91. doi:10.1016/S0016-7061 (97)00012-8

Buytaert W, Deckers J, Dercon G, Biévre B, Poesen J, Govers G (2002) Impact of land use changes on the hydrological properties of volcanic ash soils in South Ecuador. Soil Use and Management 18(2), 94-100. doi:10.1111/j.1475-2743.2002.tb00226.x

Cattan P, Cabidoche YM, Lacas JG, Voltz M (2006) Effects of tillage and mulching on runoff under banana (Musa spp.) on a tropical Andosol. Soil \& Tillage Research 86(1), 38-51. doi:10.1016/j.still.2005.02.002
Cercioglu M, Anderson SH, Udawatta RP, Haruna SI (2018) Effects of cover crop and biofuel crop management on computed tomographymeasured pore parameters. Geoderma 319(1), 80-88. doi:10.1016/j. geoderma.2018.01.005

Childs CW, Matsue N, Yoshinaga N (1991) Ferrihydrite in volcanic ash soils of Japan. Soil Science and Plant Nutrition 37, 299-311. doi:10.1080/00380768.1991.10415040

Churchman GJ, Payne D (1983) Mercury intrusion porosimetry of some New Zealand soils in relation to clay mineralogy and texture. European Journal of Soil Science 34(3), 437-451. doi:10.1111/j.1365-2389.1983. tb01047.x

Clothier BE (2001) Infiltration. In 'Soil and environmental analysis: Physical methods'. (Eds KA Smith, CE Mullins) pp. 239-280. (Marcel Dekker AG: Basel, Switzerland)

Dal Ferro N, Delmas P, Duwig C, Simonetti G, Morari F (2012) Coupling $\mathrm{X}$-ray microtomography and mercury intrusion porosimetry to quantify aggregate structures of a cambisol under different fertilisation treatments. Soil \& Tillage Research 119, 13-21. doi:10.1016/j.still. 2011.12.001

Dal Ferro N, Gastelum Strozzi A, Duwig C, Delmas P, Charrier P, Morari F (2015) Application of smoothed particle hydrodynamics (SPH) and pore morphologic model to predict saturated water conductivity from X-ray CT imaging in a silty loam Cambisol. Geoderma 255-256, 27-34. doi:10.1016/j.geoderma.2015.04.019

Dane JH, Hopmans JW (2002) Water retention and storage. In 'Methods of soil analysis. Part 4. Physical methods.' (Eds JH Dane, GC Topp) pp. 671-720. (SSSA: Madison, WI, USA)

Dorel M, Reger-Estrade J, Manichon H, Delvaux B (2000) Porosity and soil water properties of Caribbean volcanic ash soils. Soil Use and Management 16(2), 133-140. doi:10.1111/j.1475-2743.2000.tb00188.x

Dörner J, Dec D, Peng X, Horn R (2010) Effect of land use change on the dynamic behavior of structural properties of an Andisol in southern Chile under saturated and unsaturated hydraulic conditions. Geoderma 159(1-2), 189-197. doi:10.1016/j.geoderma.2010.07.011

Doube M, Kłosowski MM, Arganda-Carreras I, Cordeliéres F, Dougherty RP, Jackson J, Schmid B, Hutchinson JR, Shefelbine SJ (2010) BoneJ: free and extensible bone image analysis in ImageJ. Bone 47, 1076-1079. doi:10.1016/j.bone.2010.08.023

Dubroeucq D, Geissert D, Barois I, Ledru MP (2002) Biological and mineralogical features of Andisols in the Mexican volcanic highlands. Catena 49(3), 183-202. doi:10.1016/S0341-8162(02)00043-7

Duwig C, Delmas P, Müller K, Prado B, Morin H, Ren K (2008) Quantifying fluorescent tracer distribution Fin allophanic soils to image solute transport. European Journal of Soil Science 59, 94-102.

Etchevers JD, Prat C, Balbontin C, Bravo M, Martinez M (2006) Influence of land use on carbon sequestration and erosion in Mexico, a review. Agronomy for Sustainable Development 26(1), 21-28. doi:10.1051/ agro:2005053

FAO-ISRIC-ISSS (1998) World reference base for soil resources (WRB). In 'World soil resources reports, 84'. (FAO: Rome, Italy).

Fischer RA, Santiveri F, Vidal IR (2002) Crop rotation, tillage and crop residue management for wheat and maize in the sub-humid tropical highlands: I. Wheat and legume performance. Field Crops Research 79 (2-3), 107-122. doi:10.1016/S0378-4290(02)00157-0

Galdos MV, Pires LF, Cooper HV, Calonego JC, Rosolem CA, Mooney SJ (2019) Assessing the long-term effects of zero-tillage on the macroporosity of Brazilian soils using X-ray Computed Tomography. Geoderma 337, 1126-1135. doi:10.1016/j.geoderma.2018.11.031

Gardner WR (1958) Some steady-state solutions of unsaturated moisture flow equations with application to evaporation from a water table. Soil Science 85, 228-232. doi:10.1097/00010694-195804000-00006

Gunjigake N, Wada K (1981) Effects of phosphorus concentration and $\mathrm{pH}$ on phosphate retention by active aluminum and iron of Ando soils. Soil Science 132(5), 347-352. doi:10.1097/00010694-198111000-00004 
Hepper EN, Buschiazzo DE, Hevia GG, Urioste A, Antón L (2006) Clay mineralogy, cation exchange capacity and specific surface area of loess soils with different volcanic ash contents. Geoderma 135, 216-223. doi:10.1016/j.geoderma.2005.12.005

Horváth G, Kawazoe K (1983) Method for the calculation of effective pore size distribution in molecular sieve carbon. Journal of Chemical Engineering of Japan 16(6), 470-475. doi:10.1252/jcej.16.470

Hu W, Shao M, Wang Q, Fan J, Horton R (2009) Temporal changes of soil hydraulic properties under different land uses. Geoderma 149(3-4), 355-366. doi:10.1016/j.geoderma.2008.12.016

INEGI (1999) 'Superficies Continental e Insular del Territorio Nacional.' (INEGI, D.F.: México)

Jarvis N, Larsbo M, Koestel J (2017) Connectivity and percolation of structural pore networks in a cultivated silt loam soil quantified by X-ray tomography. Geoderma 287(1), 71-79. doi:10.1016/j.geoderma.2016. 06.026

Legland D, Arganda-Carreras I, Andrey P (2016) MorphoLibJ: integrated library and plugins for mathematical morphology with ImageJ. Bioinformatics 32(22), 3532-3534.

Luo LF, Lin H, Li SC (2010) Quantification of 3-D soil macropore networks in different soil types and land uses using computed tomography. Journal of Hydrology 393, 53-64. doi:10.1016/j.jhydrol.2010.03.031

Maeda T, Takenaka H, Warkentin BP (1977) Physical properties of allophane soils. Advances in Agronomy 29, 229-264. doi:10.1016/ S0065-2113(08)60220-5

Mehra OP, Jackson ML (1960) Iron oxide removal from soils and clays by a dithionite-citrate system buffered with sodium bicarbonate. Clays and Clay Minerals 7, 317-327. doi:10.1346/CCMN.1958.0070122

Mele G, Terribile F, Moreau E (2000) Soil structure characterization of selected European volcanic soils. Agricoltura Mediterranea 130(3-4), 247-256.

Müller K, Duwig C, Prado B, Siebe C, Hidalgo C, Etchevers J (2012) Impact of long-term wastewater irrigation on sorption and transport of atrazine in Mexican agricultural soils. Journal of Environmental Science and Health. Part. B, Pesticides, Food Contaminants, and Agricultural Wastes 47(1), 30-41. doi:10.1080/03601234.2012.606416

Müller K, Katuwal S, Young I, McLeod M, Moldrup P, de Jonge LW, Clothier B (2018) Characterising and linking X-ray CT derived macroporosity parameters to infiltration in soils with contrasting structures. Geoderma 313, 82-91. doi:10.1016/j.geoderma.2017.10.020

Münch B, Holzer L (2008) Contradicting geometrical concepts in pore size analysis attained with electron microscopy and mercury intrusion. Journal of the American Ceramic Society 91(12), 4059-4067. doi:10.1111/j.1551-2916.2008.02736.x

Nanzyo M (2002) Unique properties of volcanic ash soils. Global Environmental Research 6(2), 99-112.

Nanzyo M, Dahlgren RA, Shoji S (1993a) Chemical characteristics of volcanic ash soils. In 'Volcanic ash soils, genesis, properties and utilization'. (Eds S Shoji, M Nanzyo, RA Dahlgren) pp. 145-187. (Elsevier: Amsterdam, Netherlands)

Nanzyo M, Dahlgren RA, Shoji S (1993b) Physical characteristics of volcanic ash soils. In 'Volcanic ash soils, genesis, properties and utilization'. (Eds S Shoji, M Nanzyo, RA Dahlgren) pp. 189-207. (Elsevier: Amsterdam, Netherlands)

Navarro H, Zebrowzki C (1992) Análisis agronómico comparativo on tepetate, Suelos volcanicos endurecidos. Terra (Helsinki, Finland) 10, 451-459.

Nimmo JR (2004) Porosity and pore size distribution. In 'Encyclopedia of soils in the environment' (Ed. D. Hillel) pp. 295-303. (Elsevier: London)

Ordóñez I, López IF, Kemp PD, Descalzi CA, Horn R, Zúñiga F, Dec D, Dörner J (2018) Effect of pasture improvement managements on physical properties and water content dynamics of a volcanic ash soil in southern Chile. Soil \& Tillage Research 178, 55-64. doi:10.1016/j.still.2017.11.013

Parfitt RL (1980) Chemical properties of variable charge soils. In 'Soils with variable charge'. (Ed. KG Theng) pp. 167-194. (New Zealand Society of Soil Science: Lower Hutt, New Zealand)

Parfitt RL, Henmi T (1980) Structure of some allophanes from New Zealand Clays and Clay Minerals 28(4), 285-294. doi:10.1346/CCMN. 1980.0280407

Parfitt RL, Saigusa M (1985) Allophane and humus-aluminum in Spodosols and Andepts formed from the same volcanic ash beds in New Zealand. Soil Science 139(2), 149-155. doi:10.1097/00010694-19850200000008

Parfitt RL (1990) Allophane in New Zealand — a review. Australian Journal of Soil Research 28, 343-360. doi:10.1071/SR9900343

Poulenard J, Bartoli F, Burtin G (2002) Shrinkage and drainage in aggregates of volcanic soils: a new approach combining mercury porosimetry and vacuum drying kinetics. European Journal of Soil Science 53(4), 563-574. doi:10.1046/j.1365-2389.2002.00459.x

Prado B, Duwig C, Hidalgo C, Gómez D, Yee H, Prat C, Esteves M, Etchevers JD (2007) Characterization, functioning and classification of two volcanic soil profiles under different land uses in Central Mexico. Geoderma 139(3-4), 300-313. doi:10.1016/j.geoderma.2007.02.008

Prado B, Duwig C, Marquez J, Delmas P, Morales P, James J, Etchevers J (2009) Image processing-based study of soil porosity and its effect on water movement through Andosol intact columns. Agricultural Water Management 96(10), 1377-1386. doi:10.1016/j.agwat.2009.04.012

Prado B, Duwig C, Etchevers J, Gaudet JP, Vauclin M (2011) Nitrate fate in a Mexican Andosol: Is it affected by preferential flow? Agricultural Water Management 98(9), 1441-1450. doi:10.1016/j.agwat.2011. 04.013

Rodriguez Tapia S, del Carmen Gutiérrez MC, Hidalgo CM, Ortiz CAS (1999) Weathering of Tepetates and volcanic ashes and their influence on the formation of Andisols. Terra (Helsinki, Finland) 17(2), 97-108.

Seki K (2007) SWRC fit - a nonlinear fitting program with a water retention curve for soils having unimodal and bimodal pore structure. Hydrology and Earth System Sciences Discussions 4, 407-437. doi:10.5194/ hessd-4-407-2007

Semarnat CNA (2000) 'Situación del Subsector Agua Potable, Alcantarillado y Saneamiento a Diciembre de 1999.' (CNA: Mexico)

Shoji S, Nanzyo M, Dahlgren RA (1993) 'Volcanic ash soils: genesis, properties and utilization.' (Elsevier: Amsterdam, Netherlands)

Vandervaere JP, Vauclin M, Elrick DE (2000) Transient flow from tension infiltrometers. Part 1. The two-parameter equation. Soil Science Society of America Journal 64, 1263-1272. doi:10.2136/sssaj2000.6441263x

Vingiani S, Mele G, De Mascellis R, Terribile F, Basile A (2015) Volcanic soils and landslides: a case study of the island of Ischia (southern Italy) and its relationship with other Campania events. Solid Earth 6(2), 783-797. doi:10.5194/se-6-783-2015

Viramontes D, Esteves M, Descroix L, Duwig C, Rojas-Rojas F, Gutierrez A, de Leon-Mojarro B (2008) Quantification of runoff and erosion in an experimental Andosol watershed in Valle de Bravo. Ingenieria Hidraulica en Mexico 23(3), 89-103.

Vogel HJ (2002) Topological characterization of porous media. In 'Morphology of condensed matter' (Eds K Mecke, D Stoyan). Lecture Notes in Physics, vol 600. (Springer: Berlin, Heidelberg, Germany)

Warkentin BP, Maeda T (1980) Physical and mechanical characteristics of andisols. In 'Soils with variable charge'. (Ed. BKG Theng) pp. 281-302. (New Zealand Society of Soil Science: Lower Hutt, New Zealand)

Watson K, Luxmoore R (1986) Estimating macroporosity in a forest watershed by use of a tension infiltrometer. Soil Science Society of America Journal 50, 578-582. doi:10.2136/sssaj1986.0361599500 $5000030007 \mathrm{x}$ 
White I, Sully MJ (1987) Macroscopic and microscopic capillary length and times scales from field infiltration. Water Resources Research 23, 1514-1522. doi:10.1029/WR023i008p01514

Wooding R (1968) Steady infiltration from a shallow circular pond. Water Resources Research 4, 1259-1273. doi:10.1029/WR004i006p01259

Zong Y, Yu X, Zhu M, Lu S (2015) Characterizing soil pore structure using nitrogen adsorption, mercury intrusion porosimetry, and synchrotron-radiation-based X-ray computed microtomography techniques. Journal of Soils and Sediments 15, 302-312. doi:10.1007/s11368-014-0995-0 